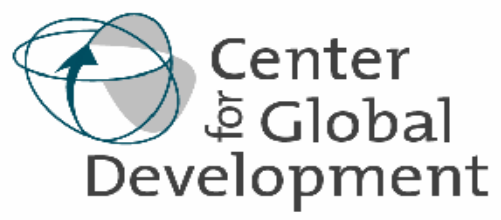

\title{
The Day After Comrade Bob: Applying Post-Conflict Recovery Lessons to Zimbabwe
}

\author{
By Todd Moss and Stewart Patrick
}

\begin{abstract}
Zimbabwe is a country in deep economic and political crisis, but also one whose situation could change quickly. Waiting until the day after the fall of Robert Mugabe could be too late, so the international community should start preliminary planning now for responses to a transition in Zimbabwe. Given the war-like trauma experienced by the country and acute conditions today, any donor strategy cannot be limited to traditional development practice but must be informed by recent post-conflict experiences. This paper lays out a framework for an international effort and identifies priority actions to support a political transition and economic recovery. It also suggests some immediate steps that the US and other donors can take, including the formation of a Commission for Assistance to a Free Zimbabwe. Beginning the planning process now is not only prudent, but such a public effort could also be catalytic: letting the Zimbabwean people know they have not been forgotten and that the world stands ready to help once Robert Mugabe is gone could perhaps help to bring about that day a little sooner.
\end{abstract}

The Center for Global Development is an independent think tank that works to reduce global poverty and inequality through rigorous research and active engagement with the policy community.

Use and dissemination of this Working Paper is encouraged, however reproduced copies may not be used for commercial purposes. Further usage is permitted under the terms of the Creative Commons License. The views expressed in this paper are those of the author and should not be attributed to the directors or funders of the Center for Global Development. 
The Day After Comrade Bob:

Applying Post-Conflict Recovery Lessons to Zimbabwe

\author{
Todd Moss and Stewart Patrick ${ }^{1}$
}

\footnotetext{
${ }^{1}$ Todd Moss (tmoss@cgdev.org) and Stewart Patrick (spatrick@cgdev.org) are Research Fellows at the Center for Global Development. The authors thank Robert Rotberg, Milan Vaishnav, Greg Michaelidis, and Kaysie Brown for comments on an earlier draft. The views expressed and any errors are strictly those of the authors.
} 


\section{Introduction}

It is not too early to start planning for a post-Mugabe Zimbabwe. The southern African country is in a perilous state of decline and could face a major transition at any time. The government, led since independence in 1980 by President Robert Mugabe and his Zimbabwe African National Union-Patriotic Front (ZANU-PF), appears impervious to international pressure to reform or even moderate political repression and disastrous economic policies. Zimbabwe is now an international pariah, having quit the Commonwealth, nearly been expelled from the International Monetary Fund, and listed by US Secretary of State Condoleezza Rice as an 'outpost of tyranny' alongside the likes of Burma and North Korea. It is also clear that the situation inside the country is both extremely fragile and ultimately unsustainable: tensions are high, there are serious divisions within the ruling party and the military, and the economy is dangerously close to outright collapse. Importantly, this precarious state of affairs is being held together mainly by Mugabe himself. Although resilient and politically cunning, he is nonetheless 81 years old.

Once Mugabe is gone, the reality of his misrule will be immediately faced by a new government. Several post-Mugabe scenarios are possible, including a transition to a handpicked successor, the rise of a reformist faction within ZANU-PF, a broad government of national unity, a military coup, or even a descent into chaos. It is of course impossible to predict the outcome. What is likely is that the change will come without much warning and that a speedy and substantial international response will be necessary. Without presuming any particular configuration, this paper assumes that the next government is reform-minded enough that it seeks a genuine normalization of external relations and that the new leadership is sufficiently distanced from Mugabe and his cronies that the international community is willing to respond in kind.

However the transition unfolds the United States and the international community should avoid getting caught flat-footed. As in post-conflict situations, Mugabe's departure will create a brief "golden hour," a fluid situation in which expectations are high and multiple possibilities quickly emerge. The international community can exploit this window of opportunity through targeted interventions to help set Zimbabwe on the right path to sustainable peace and recovery. Once this window closes, the odds of making a difference will become much longer.

Based on these assumptions, this paper argues that (1) the international community should start preliminary planning now for possible responses to a transition in Zimbabwe because (as with Cuba) waiting until the day after the fall of the dictator could be too late, and (2) given the acute conditions in Zimbabwe today, this response cannot be limited to traditional development practice but must be informed by recent post-conflict experiences. While Zimbabwe presents unique challenges of its own, the lessons learned from war-torn countries like Afghanistan, Bosnia, East Timor, El Salvador, Liberia, and Mozambique can be instructive in thinking about how to respond to a post-Mugabe era. 


\section{Why treat Zimbabwe as a post-conflict situation?}

Zimbabwe has not been at war since 1979, so it may seem strange to treat its upcoming transition as a post-conflict one. Even the recent upsurge of political violence since 2000 has been fairly low-level and never approached a full blown civil war. But the country nonetheless exhibits many extreme characteristics of a society in violent conflict.

- The scale of economic collapse. Zimbabwe's economy has shrunk by a third since 1999, a far worse decline than was seen during full-scale civil wars in other African countries (Figure 1). This compares to an average GDP decline in civil wars of "only" $15 \%{ }^{2}$ Indeed, the purchasing power of the average Zimbabwean has fallen so far in the past seven years that it has returned to 1953 levels $^{3}$ (Figure 2 ). About $35 \%$ of the population lived below the poverty line in 1996, but this grew to an estimated $80 \%$ by $2003 .{ }^{4}$ Inflation, which is under control in nearly every African country (the regional average is in the single digits), topped $400 \%$ in Zimbabwe in October 2005.

Figure 1: The Cost of War

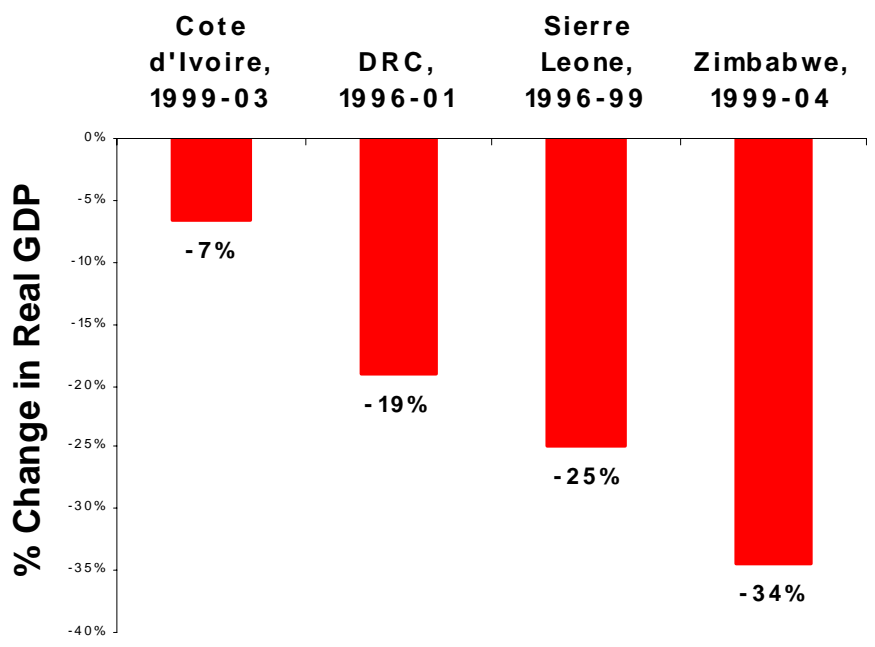

Sources: World Bank, IMF

\footnotetext{
${ }^{2}$ Paul Collier et al., Breaking the Conflict Trap: Civil War and Development Policy, World Bank, 2003.

${ }^{3}$ Michael Clemens and Todd Moss, "Costs and Causes of Zimbabwe's Crisis," Center for Global Development, July 2005.

${ }^{4}$ World Bank, World Development Indicators 2005 and IMF, “Zimbabwe: Selected Issues and Statistical Appendix," October 2005.
} 
Figure 2: Zimbabwean income, 1950-2005

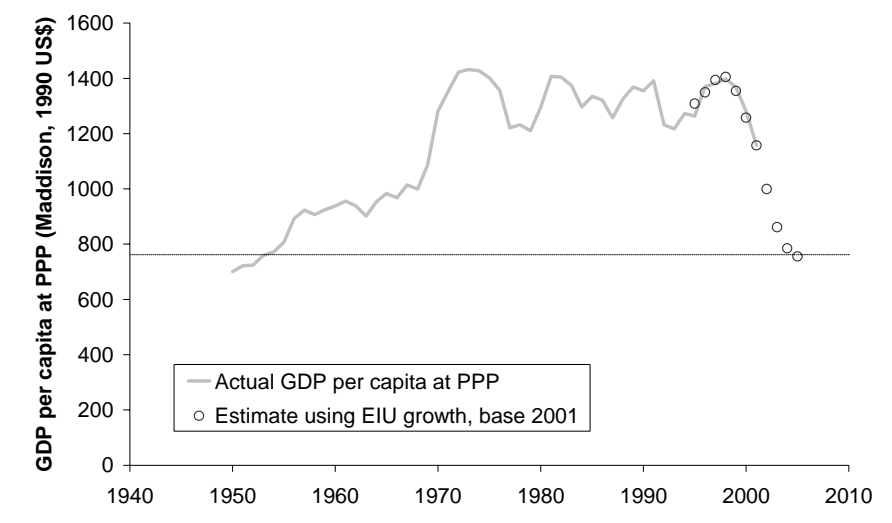

Source: Clemens and Moss (2005)

- Political violence and social trauma. Zimbabwean society has undergone intense stress stemming from organized violence and intimidation by the state. The security forces, intelligence services, and an array of government-backed militias have terrorized civilians, committed gross human rights violations, and been deployed to infiltrate and disrupt the opposition. ${ }^{5}$ In some cases, tactics from the guerilla war-including re-education camps, propaganda bombardment, and allnight pungwes - have been revived. ${ }^{6}$ Hundreds of thousands of citizens have been forcibly relocated. These conditions have produced high levels of suspicion, low levels of trust, and a steep deterioration of social capital.

- Breakdown of basic services. Although the party structure of ZANU-PF remains intact, state social services - which had once been among the best in Africa-no longer effectively function. This erosion of state services has contributed to a deterioration in already low human development indicators, dropping Zimbabwe in the UN rankings from $87^{\text {th }}$ in 1990 to $145^{\text {th }}$ by $2003 .^{7}$ The number of health professionals fleeing the country has escalated while resources for the health sector have collapsed. ${ }^{8}$

- Erosion of economic foundations. Agriculture, the mainstay of the pre-crisis economy, is a shell of its former self. Production of maize, the national staple,

\footnotetext{
${ }^{5}$ See multiple reports by the Amani Trust and the Zimbabwe Human Rights NGO Forum, including "Politically motivated violence in Zimbabwe 2000-2001," August 2001 and "Torture by State Agents in Zimbabwe: January 2001 to August 2002," March 2003.

${ }^{6}$ Norma Kriger, "ZANU(PF) strategies in general elections, 1980-2000: Discourse and coercion," African Affairs, Vol. 104, No. 414, 2005 and Kriger's Zimbabwe's Guerilla War: Peasant Voices, Cambridge University Press, 1992.

${ }^{7}$ UN, Human Development Report 2005. Zimbabwe index score on the UN's Human Development Index fell from 0.637 to 0.505 in 2003 . This drops them from the $64^{\text {th }}$ percentile ( $87^{\text {th }}$ out of 136 countries) to the $82^{\text {nd }}\left(145^{\text {th }}\right.$ out of 177$)$.

${ }^{8}$ Michael Clemens, “Do No Harm: Is the Emigration of Health Professionals Bad for Africa?" Center for Global Development, Forthcoming 2006.
} 
has dropped $86 \%$ between 2000 and $2005 .{ }^{9}$ The volume of tobacco exports, once the country's leading foreign exchange earner, is down by more than $60 \%$ since $2000 .{ }^{10}$ Industry, and to a lesser degree mining, have also suffered tremendously. Indicative of the scale-and tragedy - of the decline, Zimbabwe had once been a food exporter, but it is now food insecure with up to half the population reliant on imported food aid. This is mostly the result of chaotic land seizures and the departure of at least $80 \%$ of the country's commercial farmers (not drought or donor withdrawal, as the government claims). ${ }^{11}$ Violence on the farms has also led to widespread destruction of infrastructure. Just a few years ago Zimbabwe had Africa's most extensive system of dams and irrigation; today that is nearly all gone.

- De-formalization of the economy. As in war situations, most people in Zimbabwe now operate in the informal sector. The decimation of a once-considerable middle class has forced even more people to turn to the black market to survive. As in the Democratic Republic of the Congo, the industries that have endured best are mostly enclave projects like platinum mining that are physically isolated from the wider economy. Much of the remaining formal economy has been effectively captured by Mugabe's cronies, ZANU-PF leaders, and the military elite.

- Mass flight of people and capital. Officially, there were 3.4 million Zimbabweans, or nearly $30 \%$ of the population, living outside the country in $2002 .{ }^{12}$ The true number today is surely higher, with more leaving every day. In addition, there are hundreds of thousands of internally displaced people, the result of the dislocation of some 800,000 farm workers and their families since 2000 and the May-June 2005 Operation Murambatsvina which forced another 700,000 people from their homes. ${ }^{13}$ No precise figures on capital flight are available, but the collapse of the Zimbabwe dollar-losing $99.94 \%$ of its value ${ }^{14}$ against the US dollar in the past five years - reflects the extent of the financial bleeding.

There are of course differences between other countries' wars and Zimbabwe's collapse. No large scale military demobilization is required, for instance. But there will be an urgent need for reintegration of thousands of youths indoctrinated into the 'green bombers' and other government-sponsored militias implicated in intimidation and human rights violations against civilians. Perhaps most importantly, unlike many other African post-conflict situations, Zimbabwe does have recent experience with mostly functional and capable government (and even limited democracy). It also has an ample stock of talented people, even if most are now abroad. Thus the foundations for rapid institutional

\footnotetext{
${ }^{9}$ Based on estimates from Robertson Economic Information Services, Harare.

${ }^{10}$ IMF, 2005, p. 103.

${ }^{11}$ Clemens and Moss, 2005; Craig Richardson, "The Loss of Property Rights and the Collapse in

Zimbabwe", 2005, accessed on http://www.sarpn.org.za/documents/d0001190/index.php

${ }^{12}$ IMF, 2005, p. 7.

${ }^{13}$ Anna Kajumulo Tibaijuka, "Report of the Fact-Finding Mission to Zimbabwe to assess the Scope and Impact of Operation Murambatsvina by the UN Special Envoy on Human Settlements Issues in Zimbabwe," United Nations, July 2005.

${ }^{14}$ The rate has dropped from $Z \$ 55: U S \$ 1$ in 2000 to about $Z \$ 90,000$ on the current parallel market.
} 
recovery are available, a much easier prospect than trying to build from scratch, as was the case in Cambodia or Mozambique, for example.

\section{Framework for international support of Zimbabwe's recovery}

The extreme conditions nevertheless suggest that the revitalization of Zimbabwe's society and economy will require many elements typically associated with a strategy for post-conflict reconstruction. The main impetus for recovery will of course have to come from within Zimbabwe itself. Any revival will depend on domestic groups willing to reconcile and organized to rebuild. Zimbabwe is also fortunate in having South Africa, a large and relatively wealthy neighbor with a strong interest in fostering a rebound. South Africa and other regional players such as the African Union, the Southern African Development Community, and Nigeria will, however, have to be urged by the international community to increase their diplomatic involvement. Just as importantly, the major international donors - the World Bank, the IMF, UN agencies, the British and American governments, and other key players-will need to play an active role in shepherding and supporting the locally-owned recovery strategy.

Recent post-conflict experiences in poor countries provide important lessons about the priority tasks for promoting peace, stability and economic reconstruction in failed states, and about the principles that should guide donor engagement in those countries. ${ }^{15}$ The broad priority tasks especially relevant for Zimbabwe are:

$\checkmark$ Establishing security and the rule of law;

$\checkmark$ Fostering political reconciliation and legitimate institutions of government;

$\checkmark$ Rebuilding the institutional capacities of the state; ${ }^{16}$

$\checkmark$ Encouraging a comprehensive and inclusive economic recovery, including timely normalization of relations with the international community and rapid support comprised of aid, debt relief, and private finance. ${ }^{17}$

\footnotetext{
${ }^{15}$ Among a large literature, see Robert I. Rotberg (ed.), When States Fail: Causes and Consequences, Princeton University Press, 2003; Shepard Forman and Stewart Patrick (eds.), Good Intentions: Pledges of Aid for Postconflict Recovery, Center on International Cooperation, 2000; and "Play to Win: The Commission on Post-Conflict Reconstruction," CSIS and Association of the US Army, January 2003. ${ }^{16}$ Ashraf Ghani, Clare Lockhart and Michael Carnahan, "Closing the Sovereignty Gap: An Approach to State-Building," Working Paper 253, Overseas Development Institute, September 2005. Simon Chesterman, Michael Ignatieff, and Ramesh Thakur, Making States Work: State Failure and the Crisis of Governance, United Nations University Press, 2005; Francis Fukuyama, State-Building: Governance and World Order in the $21^{\text {st }}$ Century, Cornell University Press, 2004; Marina Ottaway, "Rebuilding State Institutions in Collapsed States," in Jennifer Milliken (ed.), State Failure and Reconstruction, Blackwell Publishers, 2003; Barnett Rubin, "Peace-building as State-Building," Survival Vol. 47, No. 4, Winter 20056.

${ }^{17}$ See, for example, Jean Clément (ed.), Postconflict Economics In Sub-Saharan Africa: Lessons from the Democratic Republic of the Congo, IMF, 2005; Serge Michailof, Markus Kostner, and Xavier Devictor, "Post-Conflict Recovery in Africa: An Agenda for the Africa Region," Africa Region Working Paper Series No. 30, World Bank, 2002.
} 


\section{Crucial political support}

Since Zimbabwe's troubles are at root political, getting the politics right is a necessary precondition for recovery. The key interventions where the international community can support Zimbabwean efforts to improve governance include:

1. Be ready to provide assistance to smooth the political transition. The postMugabe political configuration is impossible to predict, but there is a reasonable chance that some kind of transitional or caretaker government may become desirable. The international community must be prepared to help provide the political neutrality required for such an arrangement, including the facilitation of either a government of national unity or temporary third-party management (perhaps headed by a non-partisan Zimbabwean). Over the past decade and a half, the international community has frequently created ad hoc arrangements to support countries emerging from conflict or crisis, with a select group of countries serving in effect as shepherds of the political transition. After Mugabe departs the scene, the leading international donors might need to create a "Contact Group," as was successfully employed in Bosnia, or a regional framework similar to the "6 plus 2" formula for Afghanistan, to help nurture the internal political process and focus international attention. This arrangement would be tasked to normalize relations with the international community, manage the inflow of assistance, and lay the groundwork for credible elections and possibly a new constitution-writing effort. If security deteriorates, there might also be scope for an international observer mission, perhaps led by South Africa but under the auspices of SADC or the $\mathrm{AU}$ and backed by the major powers

2. Help to reform the security sector. Politicization and corruption of the police, military, intelligence services, and judiciary have undermined what were once professional and highly regarded institutions. International donors must be prepared to move quickly to persuade and assist the successor government in moving from a culture of violence and impunity to one of the rule of law. They should support a thorough reform of the security sector, including restructuring the "power" institutions (especially the ZNA, CIO, and ZRP), vetting officials for past abuses, training officials in civilian policing and criminal justice, mainstreaming human rights, and disbanding paramilitaries. ${ }^{18}$ In the immediate term, the abrupt demise of the Mugabe regime could paradoxically increase human insecurity by removing an unpalatable but effective system of repression. This possibility means that the international community, probably led by South Africa, should make contingency plans for temporary military intervention to ensure physical safety and public order if necessary.

3. Promote justice and reconciliation. A critical dimension in recovering from crisis is coming to terms with the past and seeking accountability for past crimes and abuses. Presumably, any such effort would not only cover recent violence, but

\footnotetext{
${ }^{18}$ Nicole Ball, "Reforming Security Sector Governance," Conflict, Security \& Development, Vol. 4, No. 3, December 2004.
} 
also the gukurahundi killings of some 20,000 people in Matabeleland in the early $1980 \mathrm{~s}^{19}$ and perhaps atrocities committed by both sides during the liberation war. The people of Zimbabwe will need to decide for themselves between pursuing a truth and reconciliation commission, as has been adopted in countries from El Salvador to South Africa, or a more punitive approach like a war crimes tribunal. ${ }^{20}$ Whichever option they choose, the donor community should provide legal and technical assistance.

\section{Necessary economic support}

Parallel with political reform will be steps necessary to revive the economy. To promote economic recovery, the international community should focus on the following areas:

1. Meet essential humanitarian needs. More than fifty percent of Zimbabwe's population currently relies on emergency assistance, and this population will continue to depend on relief during the political transition. The focus of humanitarian action must be on ensuring protection, food and shelter for IDPs, while seeking durable solutions that provide livelihoods and permit their orderly return and reintegration into communities. Although donors once spoke of a linear "relief to development continuum," they have discovered that in practice relief, reconstruction and development proceed simultaneously in different parts of a post-crisis country. ${ }^{21}$ One challenge for international donors will be to continue meeting immediate food requirements without undercutting the revival of local agricultural markets. ${ }^{22}$ Donors must also continue to support efforts to address the country's HIV/AIDS crisis which is slowly showing improvements in declining infection rates.

2. Facilitate an orderly return of migrants and diaspora. Perhaps a third of Zimbabweans currently live abroad. If post-conflict situations like Afghanistan are any guide, regime change in Zimbabwe may lead many of those living in neighboring countries to vote with their feet and return in large numbers, overwhelming any rudimentary public services that remain. Donors, especially UNHCR, USAID, and the South African government, can start thinking ahead for plans to help smoothly reintegrate exiles and refugees in the region. Although many of those abroad will have means to manage their own return, particular attention should be paid to the poorest and unskilled workers who may be prematurely and haphazardly forced back by neighboring authorities without the means to resettle and rebuild. At the same time, many of the high-skill

\footnotetext{
${ }^{19}$ Catholic Commission for Justice and Peace and the Legal Resources Foundation, "Breaking the Silence. Building True Peace: A Report on the Disturbances in Matabeleland and the Midlands, 1980 to 1988," 1997.

${ }^{20}$ Jack Snyder and Leslie Vinjamuri, "Trials and Errors: Principle and Pragmatism in Strategies of International Justice, International Security, Vol. 28, No. 3, Winter 2003.

${ }^{21}$ Adele Harmer and Joanna Macrae (eds.), "Beyond the Continuum: The Changing Role of Aid Policies in Protracted Crises," HPG Research Report 18, Overseas Development Institute, July 2004.

${ }^{22}$ Christopher Barrett and Daniel Maxwell, Food Aid After Fifty Years: Recasting Its Role, Routledge, 2005.
} 
Zimbabweans are now in Europe, North America, and South Africa and may want to contribute to a recovery by either returning or investing. The donor community should ensure that its own immigration, asylum and foreign investment laws are not a barrier. ${ }^{23}$

3. Help formulate and implement a multidimensional economic recovery strategy. Although a number of external donors maintain "watching briefs" to permit modest engagement with Zimbabwe, baseline data on socioeconomic conditions in the country are rudimentary. Prior to developing a comprehensive response plan, the transitional authorities and representatives of the World Bank, the IMF, UN agencies, and select bilateral donors should undertake a joint assessment of Zimbabwe's priority needs, including evaluations of the infrastructure deficit and other areas that might be privately financed. On the basis of this assessment, international donors-probably under the auspices of the World Bank-should assist the Zimbabwean transitional authorities in developing a comprehensive National Reconstruction and Development Framework, setting out the priorities and sequence for the first five years. Any economic recovery will need to first bring the macro-economy under control, try to restore basic public services, and generate jobs. Reviving the agricultural sector (see below) and the country's HIV/AIDS control program will also be priority areas. Private investment in banking, mining, industry, and telecommunications is likely to return on its own once the business environment can be improved (especially if private property rights are restored and foreign exchange constraints are lifted), but public-private cooperation could catalyze much-needed infrastructure investment.

4. Provide coordinated assistance. The international community must help the transitional government to establish a strong national coordinating body to manage inflows and projects from multiple sources. The donors should then:

- Pledge early. A World Bank-chaired consultative group meeting could quickly mobilize official financial pledges with multi-year commitments. Particularly during the first years of the post-Mugabe era, international donors will need to provide a large proportion of the funds to meet Zimbabwe's reconstruction needs. Whereas traditional donor practice for most developing countries is to set levels of support based on performance, post-conflict countries are exceptional cases that merit "early and sustained engagement" upfront to encourage a recovering country down the right path. ${ }^{24}$ This logic also applies in the case of Zimbabwe, where the British, American, and South African governments will be strongly disposed to provide resources after Mugabe is gone.

\footnotetext{
${ }^{23}$ In the United States, for instance, Senator Joseph Biden has proposed a "return of talent" program to provide visa waivers for diaspora populations who wish to return for brief periods to lend their skills to assist political and economic transitions.

${ }^{24}$ Michailof et al., 2002.
} 
- Create a Trust Fund. While Zimbabwe's upfront financing needs will be considerable, its immediate absorptive capacity will be fairly modest. Recent findings from the post-conflict literature suggests that external assistance following crisis should taper in gradually, peaking about four years after the beginning of the transition, when in fact the reverse is the more general donor pattern (thanks to incentives in donor capitals). ${ }^{25}$ To facilitate aid coordination, ensure that recovery is driven by host rather than donor priorities, and that absorption constraints are mitigated, the international community should work with the transitional government to create a Zimbabwe Reconstruction Trust Fund (ZRTF). Two precedents for this are the current Afghan Reconstruction Trust Fund and the Holst Fund for the Palestinian Territories in the 1990s. ${ }^{26}$

- Quickly normalize Bretton Woods relations. Any successor government will immediately find a number of obstacles in the way of rejoining the international financial community, so steps will have to be taken to facilitate their re-entry. The IMF will have to re-open its office in Harare and prepare for an interim stand-by arrangement. The World Bank may need to reclassify Zimbabwe as 'IDA only' to qualify the country for greater assistance, grants, and possible debt relief. The government will also have to deal with an inherited external debt of some $\$ 5$ billion. Clearing arrears will be the first step, but the arrears accrued within the past few years account for nearly half the current debt stock, suggesting that some special dispensation may need to be found with the multilateral institutions and the Paris Club of creditors. The US and EU may need to review their sanctions legislation to ensure that it does not create a legal problem or disincentive for re-engagement or private investment. ${ }^{27}$ Zimbabwe should also be considered for preferential trade access, such as AGOA in the US or the EBA for the EU.

- Convene an investment conference. The donors can play a facilitator role in marshalling both public and private investment in infrastructure and raising awareness among potential investors. There are numerous investors, particularly in South Africa, awaiting a turnaround in Zimbabwe, and the donor community can spur inflows by helping to identify projects, assisting the national authorities in making policies that will encourage private investment, and, in some cases, using public funds or guarantees to catalyze certain kinds of investments.

\footnotetext{
${ }^{25}$ Collier, 2003. Unlike most post-conflict countries, there is unlikely to be a need for interim donor support of recurrent expenditure since revenue generation rates are fairly high; total revenue was some $34 \%$ of GDP in 2004. Zimbabwe's fiscal problem is primarily on the expenditure side.

${ }^{26}$ On the Holst Fund, see Rex Brynen, "The Palestinian Territories," in Good Intentions, pp. 237-8. More generally, see Rex Brynen, A Very Political Economy: Peacebuilding and Foreign Aid in Palestine, US Institute of Peace, 2000.

${ }^{27}$ Travel and financial sanctions by the EU and US should not pose an immediate problem since they are only targeted at individuals, but they may need to be revisited and the lists altered if they present a barrier.
} 
5. Promote a new approach to land use. Land has been a central political and economic issue for Zimbabwe for several generations. However haphazard and destructive the manner in which it unfolded, land redistribution in Zimbabwe has occurred. The goal for any transitional government will now be to find a way forward to improve land use by reinvigorating the agricultural sector in a manner that provides increased employment and productivity. Priority needs will likely include a comprehensive system of land titling and the rebuilding of the farm extension and credit system. The donor community can play an important role in assisting with the stock-taking of land use and ownership, formulation of a new agriculture strategy, and consideration (and financing) of options for further distribution. External agencies can also provide independent oversight to some kind of transparent arbitration process that is almost certainly going to be necessary as disputes over land ownership and compensation arise.

\section{Steps for the US: A Commission for Assistance to a Free Zimbabwe?}

There has been growing donor interest in ways to better engage "fragile" or weak states. ${ }^{28}$ At the same time, the international community is still struggling with how to engage with "difficult" performers which lack the will and/or capacity to deliver effective governance. ${ }^{29}$ Zimbabwe has been one of the hardest nuts to crack, with many of the major players deferring to South Africa. In addition, all too often the US and the international community have been reactive rather proactive toward countries emerging from conflict or transition from political crisis. Given the possibility of a quick change in Harare and the substantial agenda outlined above, planning for an international response to Zimbabwe should begin now.

The challenge for US policy is to arrive at a comprehensive but flexible strategy that can integrate all relevant agencies and instruments of influence to support a peaceful transition from authoritarian rule and sustainable reconstruction. Within the United States government, the locus of contingency planning for a post-Mugabe Zimbabwe should be the newly established Office of the Coordinator for Reconstruction and Stabilization (S/CRS) within the State Department, which was created in August 2004 with the explicit mandate to plan and assist the recovery of failed states and countries emerging from civil strife. S/CRS has already taken the lead in planning for a response to Sudan and has held roundtables on Haiti, Nepal, Cuba, and the Great Lakes region of central Africa. There might also be bipartisan congressional interest in creating a

\footnotetext{
${ }^{28}$ Commission on Weak States and National Security, On the Brink: Weak States and National Security, Center for Global Development, 2004; USAID, Fragile States Strategy, February 2005; DFID, Why We Need to Work More Effectively in Fragile States, January 2005; Prime Minister's Strategy Unit (UK), Investing in Prevention: An International Strategy to Manage Risks of Instability and Improve Crisis Response, PMSU, February 2005.

${ }^{29}$ The World Bank's Low Income Countries Under Stress (LICUS) unit, for example, tries to find limited engagement points in countries where normal Bank operations are deemed impossible. See World Bank, World Bank Group Work in Low-Income Countries under Stress: A Task Force Report, September 2002; See also the OECD/DAC's Working Group on Development Effectiveness in Fragile States.
} 
Zimbabwe version of the Commission for Assistance to a Free Cuba, which provided both a planning and propaganda function. ${ }^{30}$

Liaising with other partners can also start now. The UK government has a similar postconflict reconstruction unit that can play a parallel role to S/CRS. Great Britain, as the former colonial power, has a strong historical interest in helping Zimbabwe turn around and can play an important role. The World Bank, while unable to participate in actual contingency planning for diplomatic reasons, should continue to maintain its analytical and LICUS work on the country. This will be critical to enable the Bank and other donors to spring into action once the transition occurs. Nevertheless, information sharing and beginning the multilateral discussions and contingency planning now can help to ensure a more nimble an effective international response to support a post-Mugabe transition in Zimbabwe.

\section{Conclusion}

Zimbabwe is a country on the edge. It may technically be at peace, but it is suffering war-like trauma to its polity and economy. In the not-distant future, the international community will likely confront the challenge of assisting the country's difficult transition from a bleak period of economic collapse and authoritarian rule. Fortunately, the world has learned lessons from post-conflict interventions in other countries, many of which it can apply to Zimbabwe-once a new leadership is in place. No donor should provide assistance to the government at the present time since a recovery is impossible with the current leadership. But there is no time to waste in developing a multilateral framework to respond to the transition that is unavoidably coming to Harare.

There is also no reason to keep this contingency planning effort secret. Diplomatic etiquette notwithstanding, there would be considerable benefit to making this an open and consultative exercise. Letting Zimbabwe's people know that they have not been forgotten and that the world stands ready to help once Robert Mugabe is gone could even help to bring about that day a little sooner.

\footnotetext{
${ }^{30}$ Report to the President: Commission for Assistance to a Free Cuba, US Department of State, May 6, 2004.
} 